\title{
Complexity Of Annual License Notification Of Small-Medium Tax Business Taxes
}

\author{
Rahayu Asriyani and Agus Bandiyono \\ Politeknik Keuangan Negara STAN \\ Email:agusbandiyono@pknstan.ac.id; agus.bandiyono@gmail.com
}

\begin{abstract}
Abstrack: The issuance of Government Regulation 23 of 2018 is the government's effort to encourage the growth of MSMEs while simultaneously increasing MSME compliance in the taxation field. This study aims to analyze the complexity of the SME Annual Taxpayer Individual Taxpayers. This quantitative study uses a questionnaire with the UMKM Individual Taxpayer in Pondok Aren Tax Office as the respondent. Pondok Aren KPP was chosen as a research location because it is an KPP that intensively approaches UMKM. This study uses the SPT complexity variable as the dependent variable. While the independent variables are ambiguity, SPT calculation, rule details, rule changes, taxpayer accounting and tax return forms. Based on the results of the study, there are 3 variables that significantly affect the complexity of the MSME Annual Taxpayer Personal Taxpayers, these variables are the calculation of tax returns, detailed rules and rules changes.
\end{abstract}

Keywords: taxation, public sector accounting, public administration, tax accounting, complexity, state finance.

\section{INTRODUCTION}

Development of the country will develop and run smoothly if various resources are well managed and the country's national income increases to finance all expenses including development spending (Tologana, 2015). Of course, every country expects that state revenue is greater than its expenditure. Although in reality what often happens is the opposite, namely the expenditure of a country is greater than its income. (Ngadiman et al., 2017). The government uses taxes to carry out national development to achieve general welfare in various sectors of life. (Darmawan et al., 2014).

As one element of state revenue, the tax has a very large and increasingly relied on role for the development and financing of government expenditure (Fuadi and Mangonting, 2013). Taxes originating from the community play an important role as one of the largest sources of state revenue, which is used for state financing (Rondonuwu et al., 2017). In mid2018, the President ratified Government Regulation No. 23 of 2018 which regulates the taxation of Micro, Small and Medium Enterprises (MSMEs). PP 23 of 2018 reduced the MSME tax rate, which was originally at $1 \%$ to $0.5 \%$. Besides, PP 23 of 2018 provides flexibility for UMKM taxpayers to choose to utilize the final tax at a rate of $0.5 \%$ or the normal rate following Article 17 of the Income Tax Act. Aside from being a form of government support for MSME Taxpayers, PP 23 is also issued as a means of expanding the tax base. The expansion of the tax base is important with the existence of track record unsatisfactory terms of tax revenue which from 2009 to 2018 failed to reach the target set. 
In addition to expanding the tax base, optimizing tax revenue must also be supported by the commitment of registered taxpayers to voluntarily comply with their tax rights and obligations. (Dewi and Widuri, 2013) stated that taxpayers must have voluntary feelings in paying taxes because taxpayer awareness in paying taxes has an important role in increasing tax revenue. That's because taxpayer awareness has a positive effect on taxpayer compliance (Anam et al., 2017). While in Indonesia, taxpayer compliance regarding tax obligations is quite low. This is reflected in the low percentage of taxpayers' annual tax reporting obligations. For the 2017 Tax Year, there were only 10.59 million Individual Taxpayers who reported Annual Tax Returns out of a total of 18 million Individual Taxpayers who were required to report annual tax returns or only around $58.83 \%$. Whereas in the Year Director General of Taxes targets 14 million Individual Taxpayers to report their Annual Tax Return (DGT Performance Report, 2017).

(Saad, 2014) states that tax complexity is seen as a factor contributing to noncompliance behavior among taxpayers. Research conducted by (Richardson, 2006) states that complexity is the most important determinant of non-compliance behavior, regardless of education, source of income, justice, and moral tax. According to (Syakura and Baridwan, 2014), the complexity of the taxation system and financial condition has a positive effect on corporate taxpayer compliance through tax planning. But uncertainty of avoidance and individualism does not affect the level of tax fraud. (Basri, 2015). (Nugent, 2013) states that the impact of the complexity of taxation laws can affect risk behavior and cost perceptions of taxpayers related to justice. (Kirchler et al., 2006) as quoted in (Saad, 2013) in his research found that taxpayers were more likely to comply when the Tax Law was deemed not complex. In Indonesia, based on a survey on the complexity of taxation in Asia Pacific conducted by Delloite in 2017, Indonesia ranks 4th with complex taxation regulations from the 20 Asia Pacific countries studied.

(Long and Swingen, 1987) approach measuring the complexity of tax rules. The result is that six factors cause the complexity of tax rules. These six factors are ambiguity, calculations, changes, details, bookkeeping, and forms. Research on the complexity of taxation rules in Indonesia by (Yogiatma, 2015) analyzed the factors that caused the complexity of the Annual Tax Returns on Individual Taxpayers by replicating research conducted by (Long and Swingen, 1987). Besides, according to (Handayani, 2012), and (Yusro et al., 2014) 4 factors affect taxpayer compliance, namely paying tax awareness, knowledge, and understanding of tax regulations, good perceptions of the effectiveness of the taxation system and the level of trust in the taxation system. Furthermore, according to (Sulistiyono, 2012), there is one factor that affects taxpayer compliance, namely motivation. The conclusion obtained is that ambiguity, calculation, change and form factors partially have a significant effect on the complexity of the Annual Tax Return used by the Individual Taxpayer. While (Fuadi et al., 2013) and (Susmiatun and Kusmuriyanto, 2014). in his research using the service quality of tax officials, tax sanctions and compliance costs are factors that affect the compliance of UMKM Taxpayers. The results of his research are partially known that the variable quality of service of tax officials and tax sanctions have a positive effect on the compliance of UMKM Taxpayers, while the cost of compliance has a negative and significant effect on the compliance of UMKM Taxpayers. According to (Ghoni, 2012) and (Brainyyah, 2013) in his research, the factors that influence the compliance of local taxpayers are motivation and knowledge of taxation. The results of his 
research partially motivational variables have no significant effect, while tax knowledge has a positive effect on taxpayer compliance.

Notification Letter (SPT) is a letter that is used by the Taxpayer to report tax calculation and/or payment, tax object and/or non-tax object, and/or assets and liabilities under the provisions of tax legislation. (Warouw et al., 2016). Speaking of the Annual Tax Return, UMKM taxpayers are also required to report the Annual Tax Return. The tax return used by the UMKM Individual Taxpayer is the Tax Return 1770. The Tax Return 1770 is one of the three types of Tax Returns used by the Personal Taxpayer in reporting annual taxes in Indonesia. Two other tax returns are SPT 1770S (Simplified) and 1770SS (Very Simplified). Following its naming, SPT 1770 is the least simple SPT because the scope is broader than the 2 other annual Personal Tax Returns. Viewing the items main as well as the number of forms, SPT 1770 also has an item mainland the number of sheets is higher than other SPT. The use of SPT 1770 for UMKM Taxpayers is not following the spirit of the issuance of PP 23 of 2018 which promotes the simplification of collection and reduces the burden of tax administration both for taxpayers and institutions responsible for tax collection. The study was conducted at KPP Pratama Pondok Aren, which is one of the Tax Service Offices in Banten Province. One of the reasons for the selection of Pondok Aren KPP as a research location is because based on the results of preliminary interviews with the Head of the Pondok Aren KPP Extensification Section it is known that the Pondok Aren KPP is one of the KPPs that is quite active in conducting education and approaches to MSME Taxpayers. The approach was carried out among other things through entrepreneurship seminars and tax education, entering the MSME community and introducing the social media slogan Pondok Aren KPP as "MSME Partners". Besides, Pondok Aren KPP was also chosen as the Best Service Office in the Ministry of Finance in 2017 (kemenkeu.go.id). Pratama Pondok Aren KPP is also in Banten Province, which is the province with the 6th largest UMKM income tax payer in Indonesia (finance.detik.com). Another reason is the Pondok Aren KPP Pratama is the only Tax Service Office located within the campus area, namely the PKN STAN Department of Education, making it suitable and often used as a location for learning and research. The difference between this research and previous studies is that the object of research is focused on testing the complexity of the tax return used by the UMKM taxpayer, namely the SPT 1770. This is following the urgency of selecting research objects as described previously.

The study was conducted by replicating research conducted by (Long and Swingen, 1987) to determine the effect of ambiguity, calculation of tax returns, detailed rules, changes in rules, bookkeeping taxpayers and tax return forms on the complexity of the annual tax returns used by MSME private taxpayers. The purpose of this study was to determine the effect of variables in the study of the complexity of the Annual Tax Return forms used by the UMKM Individual Taxpayer in Indonesia.

\section{THEORETICAL REVIEW}

Agency Theory. According to (Bandiyono and Murwaningsari, 2019), agency theory is based on the existence of agency relationships. An agency relationship is a contract in which one or more owners of economic resources (principles) involve other parties (agents) to manage these resources on behalf of the principal. (Hendriksen and Michael, 2000) state agency theory as the contract agreed between the agent and the principal with the agent's 
obligation to perform certain tasks for the principal and the principal to reward the agent. In running the country, the government and the people also have agency relations. States that to achieve prosperity, the people give authority to the government to run the wheels of government. In carrying out tax administration, agency theory can also be applied. Taxpayers act as principals and Fiscus act as agents. Fiscus makes contracts to carry out tax collection tasks to finance the administration of the state and in return for the principal is obliged to provide salary compensation to agents. Agency Problems arise when there is information asymmetry because agents have information about the taxation system that is better than the principal. Fiskus does not maximize the information it has to carry out its duties in carrying out tax collection. This causes the principal loss due to inadequate collection results due to inadequate services provided by the principal. In this case, the form of service referred to is a simple and easy service related to the implementation of the taxpayer's tax obligations.

Tax Complexity Tax. Compliance is defined as one complex thing that is seen from various perspectives (Bandiyono and Augustine, 2019). If the system contains many components that interact with and influence each other, but at the same time it is not very clear the interaction relationship between these components, the system will become complex. Whereas (Ulph, 2013) explains that what is meant by the taxation system is a series of laws that determine various tax rates for individuals and companies as well as the obligations attached to various transactions carried out by individuals and companies. Imposing sanctions that are burdensome and fair to taxpayers who try to find loopholes or even violate laws are expected to be compliant (Aisyahyusanti and Arifin, 2016).

Dimensions of Tax Complexity. What is meant by ambiguity are two or more interpretations of meaning that depend on a form. Role ambiguity is defined as a condition in which information relating to a particular role is lacking or unclear (Ramadhanty, 2013). Whereas (Borrego et al., 2016) summarize research from (Long and Judyth, 1987), (Green, 1994) and (McKerchar, 2005) stating there are 3 causes for the complexity of tax regulations related to ambiguity, namely ambiguity in the regulation of income taxation, ambiguity in the regulation of tax problems and ambiguity as well as uncertainty in tax law.

For the definition of calculation as a dimension of tax complexity (Long and Judyth, 1987) states that what is meant by calculation as a factor of tax complexity is the number of calculations that must be carried out in carrying out tax provisions. Whereas (Borrego et al., 2016) summarize research from (Long and Judyth, 1987), (Green, 1994) and (McKerchar, 2005) stating difficulties in calculating taxes arise because too many calculations and calculations are too difficult to do.

Changes to tax regulations certainly make the complexity and detail of tax rules that must be obeyed by taxpayers. (Kurniawan and Sadjiarto, 2013). Detailed rules according to (Long and Judyth, 1987) are excessive details on rules such as the number of rules and exceptions in the rules. Whereas (Borrego et al., 2016) summarize research from (Long and Judyth, 1987), (Green, 1994) and (McKerchar, 2005) stating detail in tax rules due to a large number of rules, exceptions and detailed record keeping.

(Long and Judyth, 1987) state that what is meant by change as a factor of tax complexity is the frequent change of rules or new rules that occur not long since the study. Whereas Borrego et al (2016) summarize research from (Long and Judyth, 1987), (Green, 
1994) and (McKerchar, 2005) the frequent changes in taxation rules cause complexity in taxation rules.

In the taxation provisions in Indonesia, bookkeeping is regulated by Law Number 28 Year 2007. In article 1 number 26 it is stated that the definition of bookkeeping is the financial statements prepared at the end of the tax year ending in the form of a balance sheet and income statement formed from the recording process carried out by regularly to collect data and financial information that includes assets, liabilities, capital, income, and costs as well as the total acquisition and delivery price of goods or services. (Long and Judyth, 1987) state that what is meant by bookkeeping as a dimension of tax complexity is a specific, detailed record that must be kept as a tax administration completeness.

What is meant by the form in this study is the Annual Tax Return form. Based on Article 1 of Law Number 28 the Year 2007 Annual Notification Letter is a letter which according to taxation provisions is used by the Taxpayer to report the calculation and payment of taxes, tax objects, not tax objects as well as assets and liabilities. Whereas (Borrego et al., 2016) summarize research from (Long and Judyth, 1987), (Green, 1994) and McKerchar (2005) stating the causes of complexity in taxation forms are confusing tax forms and instructions in confusing tax forms.

Micro, Small and Medium. Taxpayers who have certain gross circulation as referred to in PP 23 of 2018 are individual taxpayers and corporate taxpayers who earn income with gross circulation do not exceed Rp4,800,000,000.00 in one tax year.

The Micro Small Medium Taxpayer Tax Return Annual Tax Return Form. Used by the UMKM Taxpayer in reporting annual tax according to Per-36 of 2015 is SPT 1770. SPT 1770 itself consists of a master form and several attachments. The attachment form for SPT 1770 includes 1770-I, 1770-II, 1770-III and 1770-IV. The master form itself contains the Taxpayer Identity, Net Income, Taxable Income, Debt Income Tax, Tax Credit, Underpayment Income Tax, Installments Income tax returns for the next 25 years and attachments and statements.

\section{Framework for Thinking}

While the framework for this research is presented in Figure 1 
Figure 1. Framework for Research Research

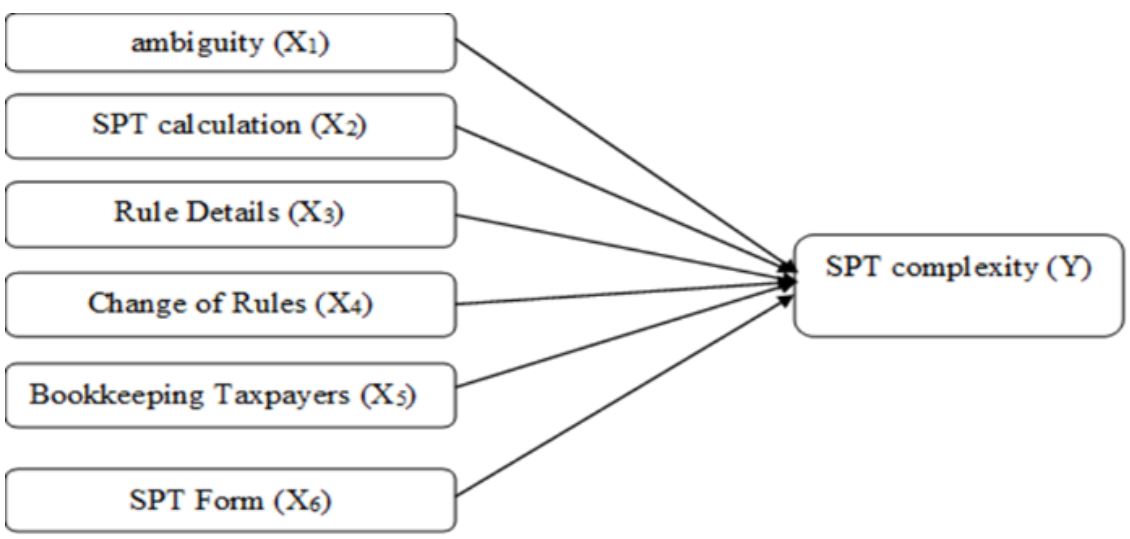

Source: (processed from Long and Swingen, 1987)

The hypothesis of this study is as follows:

$\mathrm{Ha}_{1}$ : Ambiguity affects the complexity of the Annual Tax Returns WP OP UMKM

$\mathrm{Ha}_{2}$ : Calculation of SPT affects the complexity of Annual Tax Return WP WP UMKM

$\mathrm{Ha}_{3}$ : Rule Details affect the complexity of the Annual Tax Return of WP OP UMKM

Ha4: Changes to the Rules affect the complexity of the Annual Tax Return of WP OP UMKM

Ha5: Bookkeeping WP affects the complexity of the Annual Tax Return of WP OP UMKM Ha6: Form of the Tax Return affects the complexity of the Annual Tax Return of WP OP UMKM

\section{METHODOLOGY}

Population and Sample The. Study was conducted with respondents of individual taxpayers following the provisions of PP 23 of 2018 registered at the KPP Pratama Pondok Aren. The study population numbered 11,378 taxpayers. If calculated using the sampling method Slovin, the minimum number of samples needed is 100 respondents.

Research. Methods The data collection method used was a questionnaire adapted from the research of (Long and Judyth, 1987). This research is a quantitative study with inferential statistical analysis, which predicts the relationship between two variables and associative hypotheses with a judgment sampling sample of $90 \%$. The statistical application used in this study is the application of Stata Statistics Data Analysis 14.0.

Methods of Measurement of Research Variables and Operational Definitions of: 
Independent Variables. (1) Ambiguity. There are sentences or words in taxation rules that are multiple interpretations so that they are difficult to understand and confuse of Tax. (2) CalculationReturn. Many calculations need to be done to complete the Annual Tax Return following statutory provisions. (3) Change of Rules. Frequent changes rules so that taxpayers are required to always update their knowledge about tax rules. (4) Details Rules. There are many details of tax rules that must be understood by taxpayers to be able to carry out tax obligations. (5) Bookkeeping Taxpayers The number of records, documents, and supporting evidence that must be kept by taxpayers in carrying out obligations taxation. (6) SPT Form The format, guidance, and instructions in the SPT form are unclear or less systematic so it is not easy to understand.

Free variables will be measured using an ordinal scale. This ordinal scale is built based on the number of factors mentioned as the cause of the complexity of an item Annual Tax Return for UMKM Individual Taxpayers. This scale states that the category is accompanied by its ranking.

Dependent Variable. According to (Sugiyono, 2014), the dependent variable or the dependent variable is the variable that is affected or becomes the result, because of the independent variable. The dependent variable in this study is the complexity of the Annual Tax Return form used by the UMKM Individual Taxpayer. The assessment is done using a scale rating. scale The rating is the raw data in the form of numbers that are interpreted qualitatively. The form of variables in the form of a rating scale, then the dependent variable data can be directly used for analysis using the parametric approach. The assessment is done using a scale of numbers 1 to 10. Figure 1 shows that the items are Annual Tax Returnvery simple, and number 10 shows that the items are Annual Tax Returnvery complicated. Assessments given by respondents for each item will be added up and become the value of the complexity of each item.

Research Instrument Test Instrument. testing in this study uses a validity test and a reliability test. A validity test is useful for determining the validity of a questionnaire. A questionnaire is considered valid if the questions on the questionnaire can reveal something that the questionnaire will measure (Ghozali, 2013). Meanwhile, according to (Sugiyono, 2013) reliability is an instrument that if used several times to measure the same object will produce the same data. According to (Ghozali, 2013) if the test results are Cronbach Alpha valuable more than 0.6 questionnaires can be considered reliable.

Classical Assumptions Test Classical Assumptions. The test in this study uses the test for normality, multicollinearity, and heteroscedasticity. Normality testing needs to be done because there is an assumption that the residual value follows the normal distribution in the t-test and F test conducted in multiple linear regression analyses (Ghozali, 2013). Meanwhile, to find out whether there is a high or perfect correlation between independent variables in the regression model, a multicollinearity test (Ghozali, 2013) was conducted. Heteroscedasticity test aims to test whether in a regression model there is an inequality of variance from other observational residuals (Ghozali, 2013). 
Hypothesis Testing. According to (Ghozali, 2013) tool used to measure the ability of the model to explain variations in the dependent variable is called the coefficient of determination $\left(R^{2)}\right.$. The coefficient of determination is between zero and one. $R^{2}$ value ${ }_{s}$ the small means the ability of independent variables in explaining the variation of the dependent variable is very limited, and vice versa. In addition to the coefficient of determination, there is also a Root Mean Square. One measure of error in forecasting is the square root or meanRoot Mean Square. The regression model is said to be good to be used as a forecasting model if the MSE Root <Standard deviation of the dependent variable (Y).

In addition to the coefficient of determination, a t-test was also used in this study. (Priyatno, 2012) explains that to find out whether partially independent variables have a significant effect or not on the dependent variable used a t-test or partial regression coefficient test. In this study, the significance level used was $10 \%$, so that the variable would have a significant effect if the significance value of the coefficient was smaller than $10 \%$. In addition to these tests, also used the F. (Priyatno, 2012) test defines the F test or the regression coefficient test together to use to determine whether together the independent variables have a significant effect on the dependent variable.

\section{THE RESULTS OF STATISTICAL}

Description of Respondent Data. This research successfully collected 122 respondents to complete the questionnaire. The description of the respondent's description is as follows:

Table 1. Respondent Data Description

\begin{tabular}{clll}
\hline No. & Type of Business & Number & Percentage \\
\hline 1. & Services & 25 & $20.49 \%$ \\
2. & Trade & 32 & $26.22 \%$ \\
3. & Home Industry & 12 & $9.83 \%$ \\
4. & Culinary & 51 & $41.80 \%$ \\
5. & Others & 2 & $1.64 \%$ \\
\hline No & Age & Amount & Percentage \\
\hline 1. & $<25$ years & 7 & $5.73 \%$ \\
2. & 25-30 years & 33 & $27.05 \%$ \\
3. & $31-40$ years & 52 & $42.62 \%$ \\
4. & 41-50 years & 27 & $22.13 \%$ \\
5. & $>50$ years & 3 & $2.46 \%$ \\
\hline No & Education & Total & Percentage \\
\hline 1. & SMA & 28 & $22.95 \%$ \\
2. & D1 & 10 & $8.19 \%$ \\
3. & D3 & 32 & $26.22 \%$ \\
4. & D4 / S1 & 50 & $40.98 \%$ \\
5. & S2 & 2 & $1.63 \%$ \\
6. & S3 & 0 & $0 \%$ \\
\hline & Total & $\mathbf{1 2 2}$ & $\mathbf{1 0 0 \%}$ \\
\hline
\end{tabular}

Source: (Processed, 2019) 
In addition to descriptive data related to the respondent's profile, the questionnaire also contains questions regarding the method of filling the Annual Tax Return, alone or filled in by other parties, also includes questions on the duration needed in filling the Annual Tax Return.

Table 2. Data Methods for Filling Annual Tax Returns by Respondents

\begin{tabular}{clll}
\hline No & Annual Tax Return Filling & Amount & \multicolumn{1}{c}{ Percentage } \\
\hline 1. & Self-filled in & 107 & $87.70 \%$ \\
2. & Not filled in by yourself & 15. & $13.30 \%$ \\
\hline \multirow{2}{*}{ No } & Duration for filling in Annual & \multirow{2}{*}{ Number } & Percentage \\
& Tax Return & 83 & $77.57 \%$ \\
1. & Less than 1 hour & 16 & $14.95 \%$ \\
2. & 1 hour to 1 day & 7 & $6.54 \%$ \\
3. & 1 day to 1 week & 1 & $0.93 \%$ \\
4. & More than 1 week & $\mathbf{1 0 7}$ & $\mathbf{1 0 0 \%}$ \\
\hline
\end{tabular}

Source: (Processed, 2019)

Testing research Instruments. Item-item of this research in the study reliable because based on testing, the value Cronbach Alpha exceeds 0.6.

Table 3. Test Results Reliability

\begin{tabular}{l|l|l}
\hline Value Cronbach's Alpha & Requirements & Specification \\
\hline $0.8740>$ & 0.6 & Reliable \\
\hline
\end{tabular}

Source: (Adapted from the primary data with Statistics Stata 14.0, 2019)

All items have a value of $r$ count larger than $r$ table so that it can be concluded that all items valid in the questionnaire study.

Table 4. Test Results Validity of

\begin{tabular}{|c|c|c|c|c|c|c|c|}
\hline $\begin{array}{c}\text { Survey } \\
\text { Items }\end{array}$ & $r$ count & $\mathbf{r}$ & Conclusion & $\begin{array}{c}\text { Items } \\
\text { Survey }\end{array}$ & count & $\begin{array}{c}\text { tables } r \\
\text { table }\end{array}$ & Conclusions \\
\hline Item 1 & 0.2954 & \multirow{10}{*}{0.1449} & Valid & Items 11 & 0.7007 & \multirow{10}{*}{0.1449} & Valid \\
\hline Items 2 & 0.6410 & & Valid & Items 12 & 0.4733 & & Valid \\
\hline Items 3 & 0.7567 & & Valid & Item 13 & 0,6407 & & Valid \\
\hline Item 4 & 0,4147 & & Valid & Item 14 & 0,6796 & & Valid \\
\hline Item 5 & 0,6620 & & Valid & Item 15 & 0,4479 & & Valid \\
\hline Item 6 & 0,5559 & & Valid & Item 16 & 0,6486 & & Valid \\
\hline Item 7 & 0,6274 & & Valid & Item 17 & 0.6610 & & Valid \\
\hline Item 8 & 0.5123 & & Valid & Item 18 & 0,3970 & & Valid \\
\hline Item 9 & 0,4264 & & Valid & Item 19 & 0,6128 & & Valid \\
\hline Item 10 & 0,6258 & & Valid & & & & \\
\hline
\end{tabular}

Source: (Processed from primary data with Stata Statistics 14.0, 2019) 


\section{Analysis of descriptive}

Complexity rating

Table 5. Item Annual SPT MSME Taxpayer

\begin{tabular}{c|c|l|c|c}
\hline Rank & Item & \multicolumn{1}{|c|}{ Description Item } & Mean & STDEV \\
\hline 1 & Item 6 & Compensation Losses & 5.696 & 2.555 \\
\hline 2 & Item 8 & Tax rate & 5.385 & 2.992 \\
\hline 3 & Item 1 & Income from businesses or independent services & 5.268 & 2.827 \\
\hline 4 & Item 4 & Foreign Income & 4.729 & 2.828 \\
\hline 5 & Item 7 & exemption & 4.664 & 3.261 \\
\hline 6 & Item 11 & Income Tax that must be paid & 4.623 & 2.788 \\
\hline 7 & Item 13 & Income subject to final tax/final & 4.565 & 3.161 \\
\hline 8 & Item 12: & Request tax overpayments & 4.486 & 2.991 \\
\hline 9 & Item 3 & Income other resident & 4.467 & 2.416 \\
\hline 10 & Item 5 & Zakat / Donations Religious compulsory & 4.467 & 3.032 \\
\hline 11 & Item 14 & Income not included in tax object & 4,467 & 2,638 \\
\hline 12 & Item 15 & Income of wife/husband subject to tax separately & 4,431 & 2,886 \\
\hline 13 & Item 18 & List of family members & 4,401 & 3,698 \\
\hline 14 & Item 9 & $\begin{array}{l}\text { Return/deduction of income tax article 24 which has been } \\
\text { credited }\end{array}$ & 4,327 & 3,084 \\
\hline 15 & Item 2 & Income from work & 4,213 & 2,493 \\
\hline 16 & Item 19 & $\begin{array}{l}\text { List of gross income and payment of final PPh PP 46 of } \\
\text { 2013 }\end{array}$ & 4,213 & 2,721 \\
\hline 17 & Item 10 & PPh yes ng deducted/withheld others & 4.172 & 2.633 \\
\hline 18 & Item 16 & Assets at the end of the year & 3.483 & 2.113 \\
\hline 19 & Item 17 & Debt at the end of the year & 3.483 & 2.097 \\
\hline
\end{tabular}

Source: (Adapted from the primary data degan Statistics Stata 14.0, 2019)

Classical Assumption Test. Testing was performed using normality skewness and kurtosis. Test results table Skewness and Kurtosis show Prob> chi2 is 0.8484 so it can be concluded that the data is normally distributed.

Table 6. Test Results Skewness and Kurtosis

\begin{tabular}{l|l|l}
\hline Value Prob>chi2 & Requirements & Information \\
\hline 0.8921 & $>0.1$ & Normal
\end{tabular}

Source: Processed from primary data with Stata Statistics 14.0

Based on multicollinearity test results, the independent variable is multicollinearity because the VIF (Variance Inflation Factor) value is less than 10 so that the variables in the study are free from multicollinearity. 
Table 7. Test ResultsMulticollinearity

\begin{tabular}{|c|c|c|c|}
\hline Variable & VIF & Requirements & Specification \\
\hline Ambiguity & 1.87 & \multirow{6}{*}{$<10$} & Non-Multicollinearity \\
\hline Calculation of SPT & 9.57 & & Non-Multicollinearity \\
\hline Rule Details & 4.15 & & Non-Multicollinearity \\
\hline Changes & 1.62 & & Non-RuleMulticollinearity \\
\hline Taxpayers Bookkeeping & 1.97 & & Non- Multicollinearity of \\
\hline SPT Form & 2.77 & & Non-Multicollinearity \\
\hline
\end{tabular}

Source: (Processed from primary data with Stata Statistics 14.0, 2019)

In breusch-pagan testing to test heteroscedasticity the value of the $P$-value is 0.4858 which has exceeded 0.1 so that it can be concluded that the regression model is free from heteroscedasticity.

Table 8. Heteroscedasticity Test Results

\begin{tabular}{l|l|l}
\hline Value Prob $>$ chi2 & Requirements & Information \\
\hline 0.4858 & $>0.1$ & Non-Heteroscedasticity \\
\hline
\end{tabular}

Source: (Processed from primary data with Stata Statistics 14.0., 2019)

Hypothesis Testing. Based on the OLS regression test results, the $R$-squared value is 0.7371 . It can be concluded that the dependent variable can be explained by the independent variable with a percentage of $73.71 \%$. Besides, the regression model is said to be good if the MSE Root is smaller than the standard deviation of the dependent variable. The results of statistical tests produce Root MSE of 41.306, while the standard deviation for the dependent variable is 65.77762 so that the regression model in this study is quite good.

(Priyatno, 2012) explained that the t-test was carried out to find out whether partially the independent variable significantly influenced the dependent variable. In this study, the significance level used was $10 \%$, so that the variable would have a significant effect if the significance value of the coefficient was smaller than $10 \%$.

Table 9. Test Results $\mathrm{t}$

\begin{tabular}{|c|c|c|c|}
\hline Variable & Significance & Requirements & Remarks \\
\hline Ambiguity & 0.450 & \multirow{6}{*}{$<0.1$} & $\mathrm{H}_{0}$ rejected \\
\hline SPT & 0.009 & & $\mathrm{H}_{0}$ accepted \\
\hline Details Rule & 0.015 & & $\mathrm{H}_{0}$ accepted \\
\hline Changes to Rule & 0.117 & & $\mathrm{H}_{0}$ accepted \\
\hline Bookkeeping Taxpayer & 0.119 & & $\mathrm{H}_{0}$ rejected \\
\hline SPT Form & 0.159 & & $\mathrm{H}_{0}$ rejected \\
\hline
\end{tabular}

Source: (Processed from primary data with Stata Statistics 14.0, 2019)

F test results showed that the significance level (prob> F) was 0.056 . The significance is less than 0.10 so that the regression model is feasible to be used in predicting the complexity of the UMMM Personal Taxpayer Annual Tax Return. While the F-number calculated 
generated is 4.39. For $\mathrm{F}$ the table itself is obtained from the value of 2.33 . Thus it can be concluded that the $\mathrm{F}_{\mathrm{F} \text { calculated }}(4.39)$ is greater than the $\mathrm{F}_{\text {table }}(2.33)$ so that the independent variables in the study are the factors causing complexity to have a significant influence on the Annual Taxpayers Personal Taxpayers' Taxpayer Complexity complex.

\section{DISCUSSION}

The results of statistical tests show that the first hypothesis $\left(\mathrm{H}_{1}\right)$ is rejected. The ambiguity variable has no significant effect partially on the complexity of the SPT. The results of testing this first hypothesis are different from the results of research in Portugal conducted by (Borrego et al., 2016) which state that one of the determinants of tax complexity appointed by tax professionals related to tax rules is ambiguous language. Other research results whose results are also different from the results of the first hypothesis testing are the results of research conducted by (Isa, 2014). This study found three dimensions of tax complexity encountered by many corporate taxpayers in Malaysia, one of which is tax ambiguity. The ambiguity of the taxation law results in a different interpretation of the taxation law. Other studies whose results state the significant influence of ambiguity factors in tax complexity are research conducted in the UK (Green, 1994) as quoted in (Borrego et al., 2016) which states that ambiguity and uncertainty of tax rules fall within the area of tax complexity in the context of tax professionals. Another study conducted by (McKerchar, 2005) in Australia states ambiguity in the regulation of income taxation, ambiguity in the case of income taxation and ambiguity and uncertainty of tax rules in the area of tax complexity in the context of tax professionals (Borrego et al., 2016).

However, there are also studies whose results are the same as the results of testing this first hypothesis, namely research results of (Long and Judyth, 1987) which states that Ambiguity is the fourth factor added to the regression equation after the detailed, calculated and form factors. When the ambiguity factor is added, it contributes little to the strength of the explanation in the equation and has an estimated bias that does not reach statistical significance at the 0.1 level. The relative contribution of the ambiguity factor to the strength of the explanation of the equation is almost the same as if there was no ambiguity factor.

The insignificance of the ambiguity factor in this study can be interpreted that the level of ambiguity in terms contained in the taxation rules, as well as the Annual Tax Return of the UMKM Individual Taxpayer, is still at a level acceptable to the Taxpayer.

Statistical tests showed that the second hypothesis $\left(\mathbf{H}_{2}\right)$ is received. The SPT Calculation Variable has a partially significant effect on the complexity of the SPT. The results of the second hypothesis testing are in line with several previous studies. The first is a study conducted by (Long and Judyth, 1987) which states that when regressed 2 factors (out of 6 factors) alone can explain $86 \%$ of the variation in complexity scores. These two factors are the detail factor and the calculation factor. Another study whose results are similar to the results of the second hypothesis testing is research conducted by (Isa, 2014). This study found three main dimensions of tax complexity encountered by many Malaysian corporate taxpayers, one of which is tax calculation. Many corporate taxpayers have difficulty in preparing tax calculations because these preparations require great tax knowledge. Another study that has similar results is (McKerchar's, 2005) study which states that many 
calculations and calculations are difficult to enter into the area of complexity in the context of tax professionals (Borrego et al., 2016).

The calculation of tax return is one of the dimensions of complexity that significantly influences the complexity of the annual taxpayer taxpayers of MSMEs. Not all items in the tax return require calculations, but with the increasing number of types of income received by taxpayers, the more calculations that need to be done by taxpayers. In addition to the many types of income, marital status and the number of individuals that are borne by taxpayers also affect the number of calculations that need to be done by taxpayers.

Statistical test results show that the third hypothesis $\left(\mathrm{H}_{3}\right)$ is accepted. The Rules Detail variable has a partially significant effect on the complexity of the SPT. The results of the third hypothesis test have the same results as the research conducted in America by (Long and Judyth, 1987). Overall, when regressed 2 complexity factors (out of 6) alone explained $86 \%$ of the variation in complexity scores. One of the two factors is the amount of detail that exists in federal income tax returns in America. The results of other studies that support the results of the third hypothesis testing are the results of research conducted by (Borrego et al., 2016) which states that some of the causes of tax complexity designated by tax professionals related to tax rules are the dispersion of tax rules and the many exceptions in transitional rules and regulations. Similar results were also found in research conducted in the United Kingdom (Green, 1994) as quoted in (Borrego et al., 2016) which states that many tax rules fall within the area of tax complexity in the context of tax professionals. Other research conducted in Australia (McKerchar, 2005) as cited in (Borrego et al., 2016) also suggests that there are too many rules and too many exceptions to the rules of entry in the area of tax complexity in the context of tax professionals.

Detailed rules are one of the factors that significantly influence the complexity of the UMKM Individual Annual Taxpayer Tax Return. Too many detailed rules that need to be understood to be able to fill the Annual Tax Return correctly are a separate obstacle for Taxpayers in completing the Annual Tax Return.

Statistical test results show that the fourth hypothesis $\left(\mathbf{H}_{4}\right)$ is accepted. The Change of Rules variable has a partially significant effect on the complexity of the SPT. The results of testing this fourth hypothesis differ from the results of research conducted by (Long and Judyth, 1987) in the study after 4 factors were regressed (ambiguity, excessive detail, the number of calculations needed and the format of the forms and instructions) the remaining 2 factors were change and bookkeeping factors does not make a measurable contribution to predicting complexity scores. However, several other research results are in line with the results of testing this fourth hypothesis, one of which is the results of research conducted by (Borrego et al., 2016) which states that one of the causes of tax complexity designated by tax professionals is the volatility of tax rules (88\%). Two other studies that are also in line with the results of testing this fourth hypothesis are research conducted by (McKerchar, 2005) and (Green, 1994) which states that tax regulations that often change enter the area of complexity in the context of tax professionals (Borrego et al., 2016)

In this study, the change of rules is one of the dimensions of complexity that has a significant effect on the complexity of the MSME Annual Taxpayer Personal Taxpayers. One of the rules changes that occurred before this research was done was the issuance of PP 23 of 2018 replacing PP 46 of 2013. PP 23 of 2018 regulates the adjustment of the final tax 
rate for MSME Taxpayers. The regulation also provides an option for taxpayers to choose the final tax rate or use the rates available in Article 17 of the Income Tax Act. This rule change is likely to make the rule change factor a factor affecting the complexity of the Annual Tax Return.

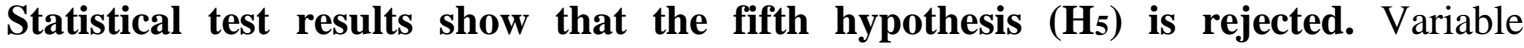
Bookkeeping Taxpayers do not have a significant effect partially on the complexity of SPT. The results of testing the fifth hypothesis are different from the results of hypothesis testing put forward by (Borrego et al., 2016) which states that one of the causes of tax complexity designated by tax professionals in the preparation of accounting information for fiscal purposes. Other research results that are also different from the results of testing the fifth hypothesis are the results of the test are the results of research conducted by (Isa, 2014). This study found three main dimensions of tax complexity encountered by many Malaysian corporate taxpayers and one of them is recording. It was stated that many corporate taxpayers had difficulty maintaining records and documents. Besides, many corporate taxpayers do not maintain proper accounting records that are needed in audit audits. However, the results of the fifth hypothesis testing are in line with the results of research conducted by (Long and Judyth, 1987) which states that the change and bookkeeping factors do not make a measurable contribution to predicting complexity scores. This is supported by the results of research in Malaysia conducted by (Pope and Abdul, 2008) who found that many small company taxpayers paid little attention to bookkeeping and tax documentation requirements (Isa, 2014).

Taxpayer bookkeeping does not have a significant effect on the complexity of the Annual Tax Return. In addition to the non-obligation of the UMKM Taxpayer to do bookkeeping, the attachments and evidence that need to be prepared to complete the Annual Tax Return are still at an acceptable level for the UMKM Individual Taxpayer.

Statistical tests showed that the sixth hypothesis $\left(\mathbf{H}_{6}\right)$ is rejected. Variable Form SPT does not have a significant effect partially to the complexity of SPT. The results of the sixth hypothesis testing are different from the results of research conducted by (Long and Judyth, 1987) which states that the form format and its instructions are complexity factors that have a significant effect after detailed and calculation factors in explaining the ranking of complexity. Other studies whose results are different are the results of research conducted in the UK (Green, 1994) as quoted in (Borrego et al., 2016) which states that confusing tax forms fall into the area of tax complexity in the context of tax professionals. Other studies conducted in Australia (McKerchar, 2005) as cited in (Borrego et al., 2016) state that confusing tax forms and tax form instructions fall into the area of tax complexity in the context of tax professionals. In contrast to the results of previous studies, respondents in this study did not find the format of the form confusing. Instructions for filling the SPT are also considered to be clear enough. Based on the results of the open-ended questions on the questionnaire, several respondents answered that the difficulty in understanding the tax return form was sufficiently overcome by the presence of the tax officer in filling out the tax return. This assistance is obtained by taxpayers online and directly when taxpayers come to the tax office. Assistance is directly obtained by taxpayers who come to the registered tax office with the assistance of tax officers at the tax office. Online DGT has also provided various information channels that can be accessed by taxpayers when they need information 
when filing their annual tax returns. These information channels include realtime chat available on the website DGT, information services by telephone with Tax Kring officers, DGT email, and also various platforms DGT social media.

\section{CONCLUSION}

This study was conducted to measure the complexity of the UMKM Personal Taxpayer Annual Tax Return by replicating the research of (Long and Judyth, 1987). The study was conducted by testing the effect of six independent variables namely Ambiguity, Calculation of Tax Returns, Rules Details, Changes to Rules, Bookkeeping Taxpayers and SPT Forms on the dependent variable, namely the complexity of the Annual Taxpayers of UMKM Individual Taxpayers. Based on the research that has been done, it can be concluded that three variables affect the complexity of the SPT, namely the SPT Calculation variable, Detail Rules, and Rules Changes.

Limitations And Suggestions. Based on these conclusions, the researcher suggested the Directorate General of Taxes to review the Annual Tax Return Form used by the UMKM Taxpayer. It is also necessary to simplify the SPT, especially in minimizing the dimensions of the complexity of the SPT calculation, rule details, and rule changes. In terms of taxpayers, it is necessary to increase education and socialization related to tax administration, especially regarding the instructions for filling the annual tax return. Whereas for further research, it is necessary to expand the scope of the research to be able to describe the UMKM Individual Taxpayer population throughout Indonesia.

\section{REFERENCES}

Aisyahyusanti, S., and Arifin, M. Z. (2016). Pengaruh penghindaran Pajak dan Sanksi Perpajakan terhadap Kepatuhan Wajib Pajak. Jurnal Perpajakan (JEJAK)|Vol, 9(1).

Anam Hairul, Butet Wulan Trifina. 2017. Factors That Affect Compulsory of Reklame Tax Requirements in The City of Balikpapan. Prosiding Seminar Nasional Manajemen dan Ekonomi Bisnis ISSN: 2579-8715.

Bandiyono, A., and Augustine, Y. (2019). Organizational Performance As A Mediation On The Effect Of Levers Of Control And Learning Organization On Tax Compliance. International Journal of Business, Economics and Law - IJBEL.

Bandiyono, A., and Murwaningsari, E. (2019). Effect of Intra Group Transaction, Thin Capitalization and Executive Characters on Tax Avoidation with Multinationality as a Moderation. Journal of Accounting, Business and Finance Research, 7(2), 82-97. https://doi.org/https://doi.org/10.20448/2002.72.82.97.

Basri, Y. M. (2015). Pengaruh Dimensi Budaya dan Religiusitas Terhadap Kecurangan Pajak. Akuntabilitas, 8(1), 61-77.

Borrego, A., E. C. Loo, C. Lopes, dan C. Ferreira. (2016). Tax Professionals' Perception Of Tax System Complexity: Some Preliminary Empirical Evidence From Portugal. Ejournal of Tax Research 13:338-360.

Brainyyah, Mariah Qibthiyyah. (2013). The Effect Of Fairness, Tax Knowledge, And Tax Complexity On Tax Compliance: The Case Of SME Entrepreneurs' Taxpayers In 
Malang. Jurnal Ilmiah Mahasiswa. Fakultas Ekonomi dan Bisnis Universitas Brawijaya.

Darmawan, I. G. H., and Sukartha, I. M. (2014). Pengaruh Penerapan Corporate Governance, Leverage, Roa, dan Ukuran Perusahaan pada Penghindaran Pajak. EJurnal Akuntansi, 143-161.

Dewi Olivia dan Widuri Retnaningtyas. (2013). Faktor-Faktor yang Mempengaruhi Keberhasilan Penerimaan Pajak. Tax \& Accounting Review.

Direktorat Jenderal Pajak. (2018). Laporan Kinerja Direktorat Jenderal Pajak 2017. Jakarta

: Kementerian Keuangan.

Fuadi, A. O., and Mangoting, Y. (2013). Pengaruh Kualitas Pelayanan Petugas Pajak, Sanksi Perpajakan dan Biaya Kepatuhan Pajak Terhadap Kepatuhan Wajib Pajak UMKM. Tax \& Accounting Review, 1(1), 18.

Ghoni, Husen Abdul. 2012. Pengaruh Motivasi Dan Pengetahuan Wajib Pajak Terhadap Kepatuhan Wajib Pajak Daerah. Jurnal Akuntansi UNNESA. Vol. 1, No 1.

Ghozali, Imam. (2013). Aplikasi Analisis Multivariate dengan Program IBM SPSS 21. Edisi

7. Semarang: Badan Penerbit Universitas Diponegoro.

Green, S. (1994). Compliance costs and direct taxation. Researchmonograph. England and Wales: The Institute of CharteredAccountants.

Handayani, Sapti Wuri; Agus Fatkhurokhman dan Umi Pratiwi. (2012). Faktor-Faktor yang mempengaruhi Kemauan Membayar Pajak Wajib Pajak Orang Pribadi yang Melakukan Pekerjaan Bebas. Jurnal Universitas Jendral Soedirman. Purwokerto: Universitas Jendral Soedirman.

Hendriksen Eldon.S. and Michael F Van Breda, (2000). Theory Accounting. alih bahasa Herman Wibowo. Batam: Inter Askara.

Isa, Khadijah. (2014). Tax Complexities In The Malaysian Corporate Tax System: Minimise To Maximise. International Journal of Law and Management. Vol. 56:50 -65.

Kirchler, E., Niemirowski, A., and Wearing, A. (2006). Shared Subjective Views, Intent to Cooperate and Tax Compliance: Similarities between Australian taxpayers and Tax Officers. Journal of Economic Psychology, 27(4), 502 - 517.

Kurniawan, C., and Sadjiarto, A. (2013). Pemahaman Kode Etik Ikatan Konsultan Pajak Mengenai Hubungan dengan Wajib Pajak oleh Konsultan Pajak di Surabaya. Tax \& Accounting Review, 1(1), 55.

Long, Susan. B., and Judyth. A. Swingen. (1987). An Approach To The Measurement Of Tax Law Complexity. Journal of the American Taxation Association. Vol. 8, no. 2: 22-36.

McKerchar, M. (2005). The Impact Of Tax Complexity On Practitionersin Australia. Australian Tax Forum, 20(4), 529---554.

McKerchar, M., Meyer, K., and Karlinsky, S. (2006). Making Progress $m$ Tax Simplification: A Comparison of The United States, Australia, New Zealand, and The United Kingdom. ATAX 7th International Tax Administration Conference.

Ngadiman, N., dan Felicia, F. (2017). Pengaruh Ekstensifikasi Pajak, Intensifikasi Pajak, Kenaikan Ptkp, Dan Tax Holiday Terhadap Penerimaan Pajak Orang Pribadi Di Jakarta Barat. Jurnal Akuntansi, 21(1), 127-142.

Nugent, David A. (2013). Legislating Morality: The Effect of Tax law Complexity on Taxpayers' Attitudes. The Journal of Applied Business Research. Vol. 29. 
Pope, J. and Abdul-Jabbar, H. (2008), Small And Medium-Sized Enterprises And Tax Complianceburden in Malaysia: issues and challenges for tax administration, The Journal of SEAANZ, Vol. 16 No. 1, pp. 47-60.

Priyatno, Duwi. (2012). Cara Kilat Belajar Analisis Data dengan SPSS 20. Edisi kesatu. Yogyakarta: Andi.

Ramadhanty, R. W. (2013). Pengaruh Pengalaman, Otonomi, Profesionalisme, Dan Ambiguitas Peran Terhadap Kinerja Auditor Pada Kap Di Diy. Nominal, Barometer Riset Akuntansi dan Manajemen, 2(2).

Richardson, Grant. (2006). Determinants of Tax Evasion : A Cross-country investigation. Journal of International Accounting, Auditing and Taxation 15(2006) 120-169.

Rondonuwu, C. W., Elim, I., and Pinatik, S. (2017). Analisis Penerapan Perhitungan Dan Pemotongan Pajak Penghasilan Pasal 21 Rumah Sakit Pancaran Kasih Manado. Jurnal Riset Akuntansi Going Concern, 12(01).

Saad, Natrah. (2013). Tax Knowledge, Tax Complexity, and Tax Compliance: Taxpayers' View. World Conference On Bussiness, Economic, and Management.

Sugiyono. (2014). Metode Penelitian Kuantitatif, Kualitatif dan R\&D. Bandung : Penerbit Alfabeta.

Sulistiono, Adincha Ayuvisda. (2012). Pengaruh Motivasi Terhadap Kepatuhan Wajib Pajak dalam Membayar Pajak Penghasilan Orang Pribadi Usahawan. Dalam jurnal Unniversitas Negeri Surabaya. Surabaya: Universitas Negeri Surabaya.

Susmiatun, S., dan Kusmuriyanto, K. (2014). Pengaruh Pengetahuan Perpajakan, Ketegasan Sanksi Perpajakan dan Keadilan Perpajakan terhadap Kepatuhan Wajib Pajak UMKM di Kota Semarang. Accounting Analysis Journal, 3(3).

Syakura, M. A., dan Baridwan, Z. (2014). Determinan Perencanaan Pajak dan Perilaku Kepatuhan Wajib Pajak Badan. Jurnal Akuntansi Multiparadigma, 5(2), 185-201.

Tologana, E. Y. (2015). Pengaruh Sanksi, Motivasi dan Tingkat Pendidikan terhadap Kepatuhan Wajib Pajak Orang Pribadi (Studi Kasus KPP Pratama Manado). ACCOUNTABILITY, 4(1), 1-11.

Ulph, David. (2013). Measuring Tax Complexity. OTS London.

Warouw, J. Z. S., Sondakh, J. J., dan Walandouw, S. K. (2016). Pengaruh Sosialisasi Perpajakan Dan Sanksi Perpajakan Terhadap Kepatuhan Pelaporan Spt Tahunan Wajib Pajak Badan (Studi Kasus Pada Kpp Pratama Manado Dan Kpp Pratama Bitung). Jurnal EMBA: Jurnal Riset Ekonomi, Manajemen, Bisnis dan Akuntansi, 3(4).

Yogiatma, Ganang. (2015). Analisis Faktor-Faktor yang Mempengaruhi Kompleksitas Surat Pemberitahuan Tahunan Wajib Pajak Orang Pribadi. Jakarta : STAN.

Yusro, H. W., dan Kiswanto, K. (2014). Pengaruh Tarif Pajak, Mekanisme Pembayaran Pajak dan Kesadaran Membayar Pajak terhadap Kepatuhan Wajib Pajak UMKM di Kabupen Jepara. Accounting Analysis Journal, 3(4). 